\title{
KETIKA SEKOLAH MENJADI PENJARA: MEMBONGKAR DILEMA PENDIDIKAN MASYARAKAT MODERN
}

\author{
Ridho Al-Hamdi \\ Program Studi Ilmu Pemerintahan Universitas Muhammadiyah Yogyakarta \\ Email: ridho_intelegensia@yahoo.co.id
}

\begin{abstract}
Abstrak
Kajian ini membahas tentang realitas dilema sistem pendidikan masyarakat modern yang terjadi di Indonesia. Sekolah sebagai lembaga resmi pendidikan menjadi satu bukti nyata gagalnya pendidikan di republik ini. Pada dasarnya, sekolah bertujuan untuk mendidik peserta didiknya menuju manusia yang cerdas dan mampu membedakan mana yang salah dan mana yang benar. Tetapi, pada kenyataannya pendidikan malah menjadikan manusia sebagai makhluk yang bodoh dan tertindas. Secara metodologis, kajian ini menggunakan metode kualitatif dengan cara wawancara dan dokumentasi untuk mendapatkan data dan informasi. Data yang sudah terkumpul dianalisa dan diintepretasikan untuk kemudian diambil sebuah kesimpulan. Berdasarkan sumber yang akurat, kajian ini membuktikan hipotesa dilema pendidikan masyarakat modern dengan menyajikan lima kasus utama dalam dunia pendidikan, yaitu adanya kurikulum yang tidak manusiawi, banyaknya kasus bunuh diri dan kekerasan terhadap pelajar, sekolah elit hanya dijadikan komoditas bisnis, buruknya hubungan antara guru, siswa, dan OSIS, dan tidak bermafaatnya kegiatan-kegiatan ekstra sekolah. Karena itu, sekarang saatnya kita menerapkan sistem pendidikan yang sesuai dengan realitas budaya multikultur di Indonesia serta hakikat dari pendidikan itu sendiri.
\end{abstract}

Kata kunci: sekolah, dilema pendidikan, masyarakat modern

\begin{abstract}
This study scrutinizes on the dilemma of educational system of modern society in Indonesia. The Educational institution so called "School" is a true evidence for this phenomenon. Ideally, the school could be educating their participants as a diligent human who know between true or false. Yet, in fact the participants continuously become a foolish and oppressed human. Methodologically, to conduct data and information, the study employs a qualitative approach as methodology as well as documentation and interviews as a technique of data-gathering. The collected data then is analyzed and interpreted descriptively to get a proper conclusion. Based on the reliable sources, this study provides five cases that took place in the Indonesia's education world. First is the unhumanist curriculum. Second are cases on the student suicide and the violence toward the student. Third is the reality of elite school as a business commodity. Fourth is the poor relationship between educators, students, and the student organization. Fifth is inexpediency of school programs for the students. Eventually, we must materialize a proper education system for Indonesian multiculturalism culture based on the essence of education.
\end{abstract}

Keywords: school, educational dilemma, modern society

\section{Latar Belakang}

Sekolah merupakan institusi bermartabat yang diharapkan dapat mendidik manusia menjadi pribadi-pribadi yang unggul, mulia, dan berwawasan luas. Sekolah diharapkan pula dapat mengeluarkan manusia dari masa kebodohan menuju masa pencerahan yang berdampak bagi kesejahteraan hidup bersama. Di sekolah, para warganya pun diharapkan dapat merasakan kenyamanan serta menemukan guru dan sahabat untuk berdiskusi bersama 
tentang kehidupan. Di sinilah letak mulianya sekolah: memfasilitasi manusia agar menemukan kesejatiannya sebagai manusia yang merdeka. Namun, impian hanyalah tinggal impian. Pada kenyataannya, sekolah tak bisa menjadikan dirinya sebagai taman bermain bagi orang yang akan mengunjunginya. Sekolah tak bisa menjadi rumah kedua setelah hiruk-pikuk di luar yang sangat kejam. Justru kekejaman dan kejahatan terjadi di lingkungan sekolah. Coba kita menengok kembali ke belakang, bagaimana kehidupan kita saat belajar di SD. Tanpa harus mengingat-ingat semua kejadian pada masa itu, keceriaan masa kanak-kanak dapat kita lihat dari foto yang terpampang di halaman pertama rapot.

Kita tentu ingat, foto yang ada di rapot selalu berukuran $3 \times 4 \mathrm{~cm}$ atau $2 \times 4 \mathrm{~cm}$, hitam putih (mungkin sudah ada yang berwarna), harus memakai dasi, wajah harus tegak menghadap ke depan, dan mayoritas foto hanya terlihat muka dan sekitarnya saja. Pengambilan foto diadakan di sekolah menjelang kelulusan atau semasa menjadi siswa. Secara teknis, kita diminta untuk berjejer empat atau lima anak, kemudian si tukang foto memotret kita. Dari sini terlihat, bahwa masa kecil kita telah dikungkung. Untuk berfoto saja harus diatur sedemikian rumit. Keceriaan kita hilang. Seharusnya, untuk urusan foto diserahkan kepada si anaknya, bebas mau berfoto gaya apa saja boleh. Dipersilakan pergi ke studio, foto bersama orang tuanya atau dengan binatang kesayangannya. Intinya, cetaklah foto yang paling disukai dan akan dipasang di dalam rapot. Namun, sepertinya hal ini tidak wajar jika ada sekolah menerapkan model seperti ini.

Semasa menjadi pelajar, kita menerima pelajaran dengan bobot yang sangat banyak, bahkan hingga 20-an mata pelajaran. Semua jenis pelajaran diberikan ke siswa, numpuk jadi satu. Belum lagi diberikan tugas rumah yang bertumpuk-tumpuk. Yang terjadi si anak bukan menjadi cerdas dan pintar, melainkan bosan, stres dan ingin lari dari sekolah. Pada saat kuliah, kita sudah dihadapkan pada pilihan ke manakah jurusan yang harus dipilih? Apakah jurusan ini mempunyai masa depan yang cerah dan pekerjaan yang jelas? Universitas pada akhirnya hanya mencetak para sarjana yang siap memburu pekerjaan, bukan sarjana yang siap menjadi pencipta lapangan kerja. Institusi pendidikan kita bukan lagi mencetak para pemimpin, melainkan sekadar menjadi mesin pencetak pelayan atau budak sesuai selera pasar. Dalam tulisan ini, penulis mencoba menguraikan tentang hakikat manusia dari perspektif eksistensialisme dan kritik terhadap masyarakat modern sebagai kerangka teoritik. Kemudian, menguraikan tentang kasus-kasus yang terjadi dalam dunia pendidikan beserta kritik-kritiknya sebagai bukti tentang adanya dilema pendidikan masyarakat modern. Setelah itu, tulisan ini diakhiri dengan kesimpulan. 


\section{Hakikat Manusia dan Perspektif Eksistensialisme}

Manusia secara bahasa, menurut Asy'arie (2002: 214-217), dapat disebut sebagai insan yang diambil dari asal kata bahasa Arab yaitu nasiya, artinya lupa. Jika dilihat dari kata dasar al-uns, artinya jinak. Karenanya, manusia memiliki sifat lupa dan jinak artinya manusia selalu dapat menyesuaikan diri dengan keadaan yang baru di sekitarnya. Pada sisi yang lain, manusia dapat disebut sebagai makhluk simbolik, karena dia mewujud dalam berbagai kebudayaan sebagai bentuk simbolis eksistensinya. Atas dasar itulah, manusia pada makna selanjutnya dapat dipahami sebagai makhluk yang berpikir yang membedakannya dengan makhluk yang lain. Manusia dapat menentukan makna keberadaannya, sedangkan makhluk yang lain tidak bisa. Karena manusia memiliki kemampuan berpikir, diharapkan manusia dapat melahirkan berbagai macam karya. Manusia yang berkualitas dapat ditentukan dari seberapa banyak karya yang telah dihasilkannya.

Dalam kita suci agama Islam (Al-Qur'an), manusia diciptakan sebagai wakil Tuhan di muka bumi ini dengan dibelaki pengetahuan konseptual serta diajarkan nama-nama benda. Karena itulah, manusia sebenarnya meneruskan tugas penciptaan Tuhan, yaitu membentuk sesuatu yang ada menjadi ada yang baru, karena alam yang ada bukan seperti benda cetakan yang sudah selesai, melainkan mengandung potensi perubahan yang berkesinambungan untuk menampung proses kreatif manusia sebagai khalifah-Nya. Jika Tuhan dapat disebut sebagai Pencipta Mutlak atau Pencipta Pertama, maka manusia adalah pencipta kedua yang sifatnya kreatif. Ketika malaikat memprotes posisi khalifah diberikan oleh Tuhan kepada manusia, maka tantangan yang disodorkan Tuhan kepada malaikat adalah tantangan kreatif. Pada akhirnya, malaikat menyadari akan kekurangannya dan menerima kenyataan itu (Asy'ari, 2001: 230-231). Lalu, malaikat bersujud kepada manusia sebagai tanda hormatnya. Sujudnya malaikat tersebut, menurut Ali Syariati, merupakan bentuk dari humanisme. Derajar manusia diangkat lebih tinggi, karena manusia memilki pengetahuan sementara malaikat tidak (Malaky, 2004).

Dalam pandangan Asy'arie (2002: 234-235), sesungguhnya manusia secara moral lebih jelek dari malaikat dan secara substansial manusia lebih jelek dari setan. Tetapi, secara konseptual manusia lebih baik daripada keduanya, karena dengan kemampuan kreatifnya, manusia mempunyai kemampuan menciptakan, suatu kemampuan yang tidak dimiliki oleh keduanya. Itulah yang menyebabkan Tuhan memerintahkan pada malaikat dan setan untuk tunduk pada manusia. Namun, setan tidak mau dan akan mengancam serta menjadi musuh abadi manusia. Setan akan senantiasa menundukkan sikap kreatif manusia dengan hawa nafsu, sehingga manusia tidak mempertuhankan Tuhan, melainkan mempertuhankan hawa 
nafsunya. Di sinilah manusia pada akhirnya disebut sebagai ciptaan Tuhan yang paling sempurna (QS. Ath-Thien: 3) dan Muhammad Iqbal, pemikir Islam asal India, mengatakan bahwa manusia adalah insan kamil (makhluk sempurna di antara makhluk-makluk yang lain).

Sedangkan Ali Syariati mengatakan, bahwa manusia itu harus menjadi insan, bukan sekadar basyar (manusia fisiologis). Basyar adalah makhluk yang sekadar 'berada' (being), sedangkan insan adalah makhluk yang 'menjadi' (becoming). Dari sekian banyak makhluk, hanya manusia saja yang dapat 'menjadi' (maju). Becoming adalah bergerak, maju, mencari kesempurnaan, merindukan keabdian, tidak pernah menghambat dan menghentikan proses terus-menerut ke arah kesempuraan. Evolusi ini adalah tanpa henti dari manusia kea rah yang tanpa batas, bergeraknya manusia ke arah kesempurnaaan ideal (Malay, 2004).

Manusia yang 'menjadi' memiliki tiga sifat yang saling berkaitan satu sama lain. Semua sifat itu adalah sifat ilahiyah dan hanya insan saja yang dapat menyesuaikan dirinya dengan sifat-sifat ketuhanan ini. Ketiga sifat itu adalah, Pertama, kesadaran (self-awareness, self-consciousness). Sifat ini menuntun manusia untuk memilih, kemudian menolongnya untuk mencipta sesuatu yang baru, yang sebelumnya tida ada di alam semesta. Kedua, kemauan bebas (free to choose). Manusia adalah satu-satunya makhluk yang bebas untuk memilih bagi dirinya, dan apa yang dia pilih bisa bertentangan dengan instinknya, dengan alam, masyarat dan dorongan psikologisnya. Kemampuan dan kebebasan berkehendak ini menolong manusia mencapi taraf tertinggi dari proses 'menjadi' manusia. Ketiga, kreativitas (daya cita, creativeness). Manusia bukan sekadar makhluk pembuat alat, tetapi ia pencipta dan pembuat barang-barang yang belum ada di alam. Manusia sadar bahwa dirinya melakukan hal-hal yang sebelumnya tidak diselesaikan oleh alam. Karena itu, dirinya membuat sendiri benda-benda guna memenuhi kebutuhannya (Malay, 2004).

Berbicara tentang karakter utama manusia yaitu kreatif, maka kita tidak bisa terlepas dari pembahasan tentang apa yang disebut dengan kebebasan (freedom). Antara creative dan freedom memiliki makna yang dekat satu sama lain. Kedua kata inilah yang juga melekat pada diri manusia. Ketika seseorang telah melakukan kegiatan yang kreatif, maka dengan sendirinya dia telah melakukan sesuatu tanpa ada paksaan dari siapapun alias bebas. Dalam tradisi filsafat, kajian ini masuk dalam pembahasan tentang eksistensialisme, yaitu satu kajian yang membahas tentang wujud eksistensi manusia dan segala persoalan dan segala persoalan yang terkait dengannya (Isma'il dan Mutawalli, 2003: 121). Manusia hidup tidak berada pada ruang yang hampa, melainkan manusia dihadapkan oleh berbagai persoalan dan krisis yang secara terus-menerus mengikutinya seiring manusia itu hidup. Di sinilah letak kajian dari eksistensialisme. 
Salah satu karakteristik yang menjadi pembahasan dalam kajian filsafat eksistensialisme adalah masalah kebebasan manusia. Menurut Jean Paul Sastre, filsuf asal Perancis, sebagaimana dikemukakan ulang oleh Isma'il dan Mutawalli (2003: 126), bahwa manusia bukanlah substansi permanen (manusia yang tak bergerak). Melainkan, manusia itu adalah eksistensi yang merdeka-temporal. Hakikat eksistensi manusia sesungguhnya adalah sebuah "proses menjadi" (process of becoming) atau transformasi dan perubahan. Nah, ketika kita sudah sampai berbicara pada pembahasan tentang kebebasan, maka tidak bisa dipisahkan dari persoalan "tanggung jawab". Antara kebebasan dan tanggung jawab merupakan dua sisi mata uang yang tidak bisa dipisahkan satu sama lain. Artinya, ketika kita melakukan suatu tindakan tertentu sesuai dengan keinginan kita sendiri, maka kita harus berpikir juga dampak yang akan diperoleh. Kita dipersilakan untuk bebas minum dan makan segala sesuatu, tetapi kita harus siap bertanggung jawab atas apa yang telah kita telan ke perut kita. Kita harus siap dengan resiko sakit yang bisa merenggut nyawa kita. Karena itu, kebebasan kita dibatasi oleh kebebasan yang lain.

Dalam konteks dunia pendidikan, kita harus dapat memahami diri kita sebagai manusia sejati yang tidak bisa dipengaruhi oleh kebijakan nasionalisasi, seragamisasi, dan segudang ide penyamarataan atas nama kebersamaan yang pada esensinya tidak mengarah pada substansi pendidikan, yaitu memerdekakan manusia dari kebodohan dan keterbelakangan. Saatnya kita berani mengatakan: Sapere Aude! Berani berpikir mandiri tanpa harus tergantung pada siapupun. Kita adalah manusia yang terus bergerak menuju sempurna sejati yang akan kembali kepada nilai-nilai ilahiyah.

\section{Kritik atas Rasionalitas Masyarakat Modem}

Menurut Kuntowijoyo (2001: 176-177), masyarakat modern atau sebutan lainnya adalah masyarakat industrial ditandai oleh tiga hal, yaitu rasionalisasi, komersialisasi, dan monetisasi. Rasionalisasi artinya, bahwa masyarakat modern lebih mendahulukan sesuatu hal yang bersifat masuk akal daripada yang tidak masuk akal. Walaupun sebagian orang masih percaya pada dunia mistik, tetapi celah untuk berkomentar dan menyalahkan terhadap sesuatu yang tidak masuk akal terus saja terjadi. Karena itu, dentuman Rene Descartes, filsuf Prancis, yang berbunyi cogito ergo sum (aku berpikir, maka aku ada) benar-benar diamini dan diyakini oleh dunia sebagai awal dari lahirnya aliran rasionalisme. Sejak saat itulah awal abad pencerahan mulai muncul, yang kemudian dilanjutkan dengan lahirnya teknologisasi pada segala bidang ilmu pengetahuan hingga sekarang. 
Komersialisasi menunjukkan, segala segmen kehidupan harus memiliki daya jual tersendiri. Tidak ada sesuatu yang tidak komersiil. Hal ini ditandai dengan maraknya program-program di televisi, bioskop, penjualan kaset $\mathrm{CD}$, buku, dan iklan-iklan di pinggir jalan maupun di televisi. Bahkan, sekarang komersialisasi terjadi pada dunia perbukuan. Ada penulis buku yang disebabkan bukunya best seller dan difilmkan, tarif untuk menjadi pembicara dalam sebuah seminar atau talkshow (sekali manggung) seharga 30 juta rupiah. Itu pun di luar transport. Selain itu juga, komersialisasi terjadi pada segmen masyarakat bawah, yaitu parkir kendaraan (motor misalnya) dan buang air kecil. Untuk kedua jasa ini kita harus mengeluarkan uang seribu rupiah. Mungkin beberapa dekade ke depan, untuk buang angin (kentut) atau bernafas saja kita harus membayar.

Monetisasi mengindikasikan bahwa semua hal harus diukur dengan uang. Ini terkait erat dengan penjelasan komersialisasi di atas. Dampak dari adanya proses komersiasliasi adalah menuntut adanya proses monetisasi (uangisasi). Uang menjadi satu bentuk konkrit atas proses yang terjadi. Makanya, banyak pemilik modal yang hanya menimbun uang dari hasil larisnya penjualan produk mereka. Rakyat bawah hanya menjadi sasaran empuk dari propaganda mereka. Rakyat tidak sadar bahwa mereka telah dihipnotis dengan rayuan iklan yang hiperbolis.

Atas realitas masyarakat modern yang demikian itu, sejumlah intelektual dari Madzhab Frankfurt Jerman melakukan kritik terhadap kebobrokan masyarakat modern. Kritik tersebut dilakukan dengan dua cara. Pertama, menelusuri kembali akar-akar kemunculan cara berpikir positivistis masyarakat modern dengan merefleksikan proses rasionalisasi di dalam masyarakat Barat. Kritik ini ada di dalam buku yang berjudul Dialektik der Aufklarung karya patungan Adorno dan Horkheimer. Kedua, menunjukkan bahwa cara berpikir positivistis yang telah mewujudkan dirinya dalam ilmu pengetahuan dan teknologi berlaku sebagai ideologi yang diterima apa adanya oleh masyarakat modern itu sendiri. Kritik ini ada di buku termasyhur karya Marcuse yang berjudul One-Dimensional Man (Hardiman, 1993: 60).

Pada cara yang pertama, Adorno dan Horkheimer mengatakan, bahwa peradaban Barat terjebak dalam cara berpikir saintis dan positivistis serta cara hidup konsumeristis yang tenggelam ke arah barbarisme baru. Pemikiran kita ditata menurut prosedur matematis sehingga dapat bekerja secara tepat dan otomatis di bawah aturan-aturan yang pasti. Pemikiran positivistis dan matematis ini dapat diulang terus di berbagai kondisi karena dianggap obyektif, tetapi pemikiran yang demikian itu nampak menjadi ritus tersendiri sehingga ilmu pengetahuan terkesan tertutup, tidak kritis dan dibatasi. Pikiran kita menjadi 
barang yang mati atau status quo dalam melihat dunia. Jika demikian, manusia rasional telah membekukan gambaran dunia menjadi ideologis (Hardiman, 1993: 60, 63-64).

Inilah yang disebut oleh Horkheimer dengan rasio instrumental, yaitu rasio yang kehilangan isi dan tujuan pada dirinya sendiri dalam memahami kenyataan. Kemudian, rasio menjadi netral dan dapat dipakai demi tujuan-tujuan di luar dirinya. Rasio menjadi tukang atau alat kalkulasi, alat verifikasi, pelayan klasifikasi yang setia pada tujuan-tujaun di luar dirinya. Pada akhirnya, rasio manusia tidak menghasilkan kemajuan apa-apa, melainkan melanggengkan kembali ilmu pengetauan sebagai mitos baru (Hardiman, 1993: 64). Rasio yang telah bersifat instrumentalis atau netral ini pada akhirnya dipakai oleh pihak-pihak yang berkepentingan untuk melanggengkan tujuannya guna meraih keuntungan sebesar-besarnya. Kita menjadi semakin paham, bahwa 'modernitas' yang kita sanjung-sanjung menjadi satu pembahasan yang gamang dan 'rasionalitas' menjadi kajian yang penuh dengan kebingungan.

Pada cara yang kedua, Marcuse menegaskan kembali kritik Adorno dan Horkeimer terhadap cara berpikir saintis masyarakat modern yang telah membeku menjadi ideologi atau mitos. Menurut Marcuse, ilmu pengetahuan dan teknologi saat ini telah menjadi sistem penguasaan yang total di dalam masyarakat. Padahal, seharusnya teknologi dapat membebaskan manusia dari tuntutan kerja keras. Teknologi yang telah menjelma di dalam industri dengan memproduksi barang-barang konsumtif tidak berujung pada welfare state alias kebahagiaan dan kebebasan. Alat-alat teknologi bukannya mengabdi pada manusia, melainkan manusia yang dikendalikan oleh alat-alat teknologi tersebut. Tanpa disadari, manusia ditelan oleh kekuasaan teknologi sebagai sistem total yang merangkum berbagai bidang kehidupan manusia. Seharusnya hukum-hukum teknologi seperti ekstensifikasi, otomatisasi, standardisasi, dan mekanisasi dapat membebaskan manusia dari kerja-kerja fisik. Tetapi yang terjadi sebaliknya, prinsip-prinsip hukum tersebut malah mengatur manusia (Hardiman, 1993: 66-67).

Masyarakat modern memang tidak lagi ditindas oleh manusia lain seperti yang terjadi pada zaman Karl Marx. Saat ini manusia ditindas oleh sesuatu yang anonim, yaitu 'sistem teknologi' yang telah mencengkeram manusia secara menyeluruh. Inilah yang disebut oleh Marcuse dengan rasionalitas teknologis, yaitu segala sesuatu dipandang rasional jika dapat diperalat, dimanipulasi, dan dimanfaatkan secara matematis dan ekonomis. Para penguasa dapat mempertahankan kekuasaannya sejauh mereka sukses memobilisasi barang-barang yang diproduksi oleh industri perusahaan. Jika demikian, ilmu pengetahuan dan teknologi telah merampas kebebasan manusia sampai ke akar-akarnya (Hardiman, 1993: 67-68). 
Di bidang ekonomi, melimpahnya beragam jenis produksi menjadikan manusia bebas memilih apa pun sesuka hatinya hingga menjadi manusia konsumeris. Pusat-pusat industri akan terus memproduksi barang sesuai selera pasar hingga yang terjadi adalah manipulasi pada manusia itu sendiri. Di samping itu juga, saat ini masyarakat modern bebas melakukan apa saja, bebas berekspresi, bebas bersarikat, bahkan bebas melakukan hubungan seksual. Namun, Marcuse mengatakan, bahwa masyarakat modern adalah 'rasional dalam bagianbagian tetapi irrasional dalam keseluruhan'. Matinya semangat perlawanan terhadap sistem teknologi telah menjadi ciri utama masyarakat modern. Inilah yang disebut oleh Marcuse sebagai masyarakat satu dimensi. Seluruh dimensi kehidupan mengarah ke satu tujuan saja, yaitu menjaga kelangsungan sistem teknologis yang telah menjadi penguasa total. Semua ini merupakan perbudakan dan penindasan terhadap dimensi-dimensi kehidupan manusia modern (Hardiman, 1993: 68-69). Sedangkan Jurgen Habermas, filsuf asal Jerman, memberikan istilah pada kesadaran masyarakat modern sebagai kesadaran teknokratis. Kesadaran jenis ini mencerminkan suatu penindasan atas dimensi etis manusia yang terkait langsung dengan kehidupan sosial politisnya. Hal ini dapat terlihat dari cara berpikir positivistis yang memuncak pada depolitisasi ilmu-ilmu sosial (Hardiman, 1993: 96).

Berdasarkan penjelasan Kuntowijoyo tentang karakteristik masyarakat modern beserta kritik dari sejumlah ilmuwan Madzhab Frankfurt, kita dapat memahami bahwa masyarakat modern saat ini menjadi manusia yang teralienasi/terasing dari dunianya sendiri. Kita sedang mengalami dilema yang berkepanjangan yang sejatinya kita sendiri tidak tahu bagaimana cara menyelesaikan dilema tersebut. Kita tidak mengenal siapa diri kita dan bagaimana sikap yang harus kita ambil terhadap realitas yang ada di sekitar kita. Kita malah membebek dengan gempuran ideologi kapitalis yang pro terhadap pemilik modal.

Ilustrasi keterasingan bisa kita terapkan ketika kita sedang berada di tengah kerumunan orang-orang yang sedang menonton konser musik. Ketika semua orang sedang loncat-loncat dan menikmati dentuman musik yang cadas, bahkan di antara mereka saling dorong sebagai bentuk kepuasan, kita seolah ingin tergerak untuk ikut bersama mereka. Jika kita tidak ikut seperti mereka dan hanya diam berdiri di tengah kerumunan tersebut, kita akan menjadi orang yang terasing. Orang-orang di sekitar kita akan menatap aneh ke arah mata kita. Dengan terpaksa kita ikut jingkrak-jingkrak sekalipun itu bukanlah diri kita yang sebenarnya. 


\section{Kurikulum yang Tidak Manusiawi}

Kita masih ingat Undang-Undang Sistem Pendidikan Nasional (Sisdiknas) tahun 2003 yang intisarinya mencerdaskan kehidupan bangsa, mengembangkan manusia yang beriman dan bertakwa kepada Tuhan Yang Maha Esa, berbudi luhur, memiliki pengetahuan, ketrampilan, kesehatan jasmani dan rohani, mempunyai kepribadian yang mantap dan mandiri, serta rasa tanggung jawab kemasyarakatan dan kebangsaan (Kompas 24/03/2007). Inilah cita-cita mulia dari pendidikan kita. Namun, kita menjadi heran ketika cita-cita mulia tersebut kontras dengan sederetan kisah para pelaku yang telah menjadi korban pendidikan. Lihat saja apa yang terjadi pada Amelia Ayu, siswi SMP Negeri I Yogyakarta.

"Saya bingung mau belajar apa, yang mana dulu yang harus dipelajari. Soalnya pelajaran di sekolah banyak banget. Padahal, waktu belajarnya kan terbatas," ungkap Amelia kepada Kompas, 9 Februari 2006.

Pelajaran di sekolahnya berjumlah sekitar 18 mata pelajaran. Hal itu membuatnya sulit untuk membagi waktu. Padahal, seperti yang diberitakan oleh Harian Kompas, Amelia sudah menyediakan empat jam untuk belajar di rumahnya.

"Hampir setiap sore saya belajar mulai jam 15.00 hingga 17.00. Malamnya mulai lagi dari jam 19.00 sampai 21.00," tuturnya.

Waktu belajar yang cukup lama itu, menurut Amelia, masih belum cukup untuk mempelajari semua tugas yang diberikan oleh sekolah. Selalu saja ada yang kurang. Hampir tidak ada waktu lagi untuk beraktivitas pada aspek ketrampilan serta pergaulan sosial. Kalau sudah begini, keceriaan yang seharusnya ada pada diri Amelia menjadi musnah. Bagi seorang anak seperti dia, pendidikan ternyata begitu "mencengkeram" hidupnya. Tidak heran, jika setiap hari seorang siswa (di Indonesia) rata-rata membawa buku 16 buah. Empat buku referensi, empat buku tugas, empat buku catatan, dan empat buku LKS. Karena rata-rata sehari ada jadwal empat mata pelajaran.

"Paling-paling pusing jika setiap mata pelajaran ada tugas yang harus dikerjakan," seloroh Amalia.

Hal yang sama pernah diungkapkan Nurul, siswi SMA Muhammadiyah Pengasih Bantul kepada Majalah Kuntum. Dia merasa jengkel berada di sekolah dari pagi hingga sore. Hal ini disebabkan karena banyaknya mata pelajaran dan ditambah dengan kegiatan ekstrakulikuler yang bersifat wajib. 
"Soal banyaknya tugas terkadang membuatku tidak enjoy berada di sekolah. Bayangkan saja kalau setiap guru memberikan PR dalam waktu yang bersamaan. Bikin bete kan,” kisahnya (Kuntum, Edisi 257/Mei 2006: 9-10).

Pengalaman Nurul di atas diperkuat lagi dengan alasan Muhammad Syafurrahman (siswa Madrasah Mu'allimin Muhammadiyah Yogyakarta) dan Kurnia Nur Kusuma Dewi (siswi SMA swasta Yogyakarta) ketika ditemui penulis tahun 2006. Rahman sangat jengkel ketika dirinya harus membawa enam sampai delapan buku pelajaran yang terdiri dari buku catatan, paket, dan buku-buku keislaman lainnya. Baginya, ini sangat membebankan. Karena apa-apa selalu dibuat susah dan banyak tugas.

"Satu guru saja bisa ngasih tugas macam-macam," keluhnya.

Menurut pengakuan Kurnia, dia harus membawa minimal 8-10 buku ke sekolah. Sungguh aktivitas yang tidak manusiawi.

Memang, mata pelajaran di negeri kita cukup banyak. Hal ini tertuang dalam UndangUndang Republik Indonesia No. 20 tahun 2003 tentang Sisdiknas pasal 37 ayat 1 yang menyatakan, bahwa kurikulum pendidikan dasar dan menengah wajib memuat mata pelajaran Pendidikan Agama, Pendidikan Kewarganegaraan, Bahasa, Matematika, IPA, IPS, Seni dan Budaya, Pendidikan Jasmani dan Olah Raga, Ketrampilan/Kejujuran, dan Muatan Lokal (Gerbang, Edisi 5 Th. III November 2003: 32).

Wajibnya saja sudah 10 mata pelajaran, belum pelajaran tambahan, ektrakulikuler, dan les-les lainnya. Pelajaran lainnya misal: IPS terbagi menjadi sejarah, ekonomi, sosiologi/antropologi, dan geografi; IPA terbagi mejadi kimia, fisika, dan biologi; Bahasa terbagi menjadi bahasa Indonesia, bahasa Inggris, dan bahasa daerah. Dalam kelas MTs/MA, pelajaran agama terbagi ke dalam bagian-bagian seperti: Qur'an-Hadits, fikih, ushul fikih, tafsir, ilmu tafsir, aqidah, bahasa Arab, akhlak, nahwu-shorof, tajwid, dan pelajaran agama lainnya. Luar biasa banyaknya. Jika sudah demikian, maka para pelajar kita akan kehilangan sisi-sisi keceriaan, pergaulan, dan ketrampilannya. Semua telah tergantikan oleh beban mata pelajaran yang didapatkannya di sekolah. Sifat keceriaannya itu sudah mulai pudar dan terkikis secara perlahan-lahan. Hidup ini terasa sesak. Tidak ada jalan lain selain harus belajar, belajar, dan belajar. Betapa sedihnya kalau hidup seperti ini. Pergaulan dengan sesama teman menjadi sangat berkurang. Tidak ada waktu luang kecuali hanya bermain dengan buku. Mungkin, pepatah yang mengatakan "Sebaik-baik teman adalah buku" kurang tepat diberlakukan dalam konteks beban pelajaran. Karena jika diberlakukan, maka anak didik kita menjadi semakin stres. 
Banyak kasus sepele lain yang dialami oleh para pelajar tetapi berdampak cukup besar. Kita pasti masih ingat kasus pelajar SMP Muhammadiyah di Playen Gunungkidul. Karena kurang dalam membayar iuran untuk rekreasi, akhirnya siswa tersebut mencoba bunuh diri degan tali rafia, tetapi gagal dan dapat diselamatkan. Belum lagi kasus anak SD yang juga mencoba bunuh diri hanya gara-gara orang tuanya tidak kuat membayar SPP senilai Rp. 2.500. Di Makassar, karena tidak lulus Ujian Nasional (UN), seorang siswa SMA lompat dari atas jembatan. Sungguh amat tragis.

Realitas-realitas tersebut tidak terlepas dengan jumlah mata pelajaran dan jam mata pelajaran yang begitu banyak. Kenyataan ini diakui oleh Tim Badan Strandar Nasional Pendidikan (BSNP), bahwa kurikulum pendidikan di negara Indonesia, baik di sekolah dasar maupun menengah, paling berat sedunia. Ini sangat memberatkan siswa dan harus dikurangi. Beban jam pelajaran di Indonesia ternyata lebih dari seribu jam per tahun. Ini diberlakukan dari SD hingga SMA. Angka ini terlama di dunia. Padahal, jumlah jam pelajaran di negaranegara Asia-Pasifik (yang bukan termasuk negara maju) hanya 900-950 jam per tahun. Negara Indonesia memang hebat, sehingga mau diambil semuanya.

Nyatalah, dunia anak yang bersekolah di Indonesia sebenarnya dunia khayal, tetapi amat melelahkan. Tidak memberikan ruang untuk bernafas. Padahal siswa sangat butuh waktu untuk tertawa, mencurahkan isi hati (curhat), atau sekadar bercanda ringan dengan teman-teman kelasnya. Karena itu, sekarang saatnya jam mata pelajaran harus dikurangi. Tentunya, pengurangan jam pelajaran siswa harus diikuti dengan dikuranginya jumlah mata pelajaran yang ada. Karena kalau tidak demikian, jam pelajaran siswa tetap saja berat. Hal ini bertujuan baik, agar pelajaran menjadi lebih fokus dan siswa konsen dengan pelajaran yang disukainya. Jadi, tidak semua mata pelajaran ditumpahkan kepada siswa. Hal ini akhirnya disadari oleh BSNP untuk mengurangi jam pelajaran. Jam pelajaran di tingkat SD per tahun paling lama 700 jam, SMP sekitar 900 jam, sedangkan di SMA/MA sekitar 1000 jam.

Sebelum berlanjut pada kasus-kasus yang terjadi dalam dunia pendidikan, penulis ingin bercerita tetang seorang anak dan sekolahnya. Alkisah, ada seorang siswa SMP yang ditanya pamannya tentang mata pelajaran apa yang paling disukainya. Dengan enteng si anak menjawab:

"Ada tiga, Om. Waktu istirahat, saat pelajaran kosong, dan ketika pulang sekolah."

Sejenak sang paman kaget dan berpikir mengapa keponakanku menjawab demikian. Pikir sang paman, si anak seharusnya menjawab: "Saya suka pelajaran-pelajarannya, gurunya ramah-ramah, dan suasana kelas kondusif untuk belajar". 
Jawaban si anak cukup beralasan karena dia sudah sekian lama belajar di sekolah. Selama itu pula ia merasa tidak mendapatkan kenyamanan. Pendidikan baginya begitu menakutkan. Jika tidak mengerjakan tugas, akan dihukum keliling lapangan. Jika tidak mengerjakan PR, disuruh push up 100 kali. Jika guru menerangkan siswa harus diam dan mencatat apa yang diterangkan di papan tulis. Jika ada siswa yang mengritik, dianggap menantang. Siswa diminta harus menghafalkan bacaan sesuai dengan teksnya. Jika tidak sesuai, diminta untuk mengulangi lagi sampai benar.

Dalam pikiran si anak, lembaga pendidikan itu bertujuan untuk memanusiakan manusia. Maksudnya, sekolah atau lembaga pendidikan lainnya seharusnya mampu menjadikan orang bodoh menuju pintar, serta menjadikan peserta didik nyaman dan enjoy dalam belajar. Karena itu, adanya jurusan di masing-masing sekolah hanya sebagai sarana untuk menuju hidup yang aman dan tentram. Namun, apa yang dipikirkan oleh si anak di atas sangat jauh dari harapan. Sekarang, orientasi siswa belajar hanya untuk mencari uang. Dalam belajar siswa sudah memikul beban bahwa dia harus mampu meraih cita-citanya. Karena beban yang cukup berat itu, ada siswa yang tidak kuat melakukannya. Karena itu, ketika Ujian Nasional (UN) tidak lulus maka siswa tersebut langsung shock dan merasa dirinya bodoh di antara teman-temannya yang lulus.

Kini keceriaan siswa telah direbut oleh lembaga bernama "sekolah". Setiap hari, siswa harus berangkat ke sekolah sebelum jam tujuh pagi. Di kelas mereka diajarkan beragam mata pelajaran dari sosial hingga eksak. Kemudian pulang saat matahari hampir terbenam. Ketika sampai di rumah, tugas menumpuk. Dengan terpaksa mereka mengerjakannya sembari terkantuk-kantuk. Setelah mengerjakan tugas, rasanya badan harus istirahat. Lalu tidurlah siswa tersebut hingga keesokan harinya untuk menjemput kembali ke sekolah. Begitulah rutinitas pribadi seorang pelajar. Keceriaan yang seharusnya ada pada seumuran mereka hilang secara perlahan-lahan. Karena itu, saatnya kita menjadikan sekolah sebagai taman bermain bagi para pelajar. Guru bukanlah monster yang harus ditakuti, tetapi guru menjadi mitra bermain sekaligus pembimbing dalam membentuk kepribadian pelajar. Pelajar adalah mutiara bangsa yang harus tetap dijaga keutuhannya. Tanpa mereka bangsa ini tidak akan hidup dengan cerah.

Sebenarnya persoalan mendasar dari pendidikan di Indonesia ini tidak terlepas dengan selalu bergantinya kurikulum seiring dengan bergantinya menteri. Ketika tahun 2004, sistem pendidikan Indonesia menggunakan KBK (Kurikulum Berbasis Kompetensi), kemudian tahun 2006 berubah dengan sistem KTSP (Kurikulum Tingkat Satuan Pendidikan). Entah apalagi perubahan yang akan terjadi di masa mendatang. Tidak masalah adanya 
pergantian kebijakan. Justru dengan adanya pergantian kebijakan, semakin menunjukkan kedinamisan pendidikan kita. Namun, yang menjadi dasar semuanya adalah, apakah pergantian kebijakan tersebut merupakan sesuatu hal yang sangat fundamental? Ini pertanyaan yang harus dijawab oleh semua pihak.

Jika perubahan selalu dilakukan dan tidak berdampak positif, maka hanya akan menyebabkan pembengkakan biaya. Kalau begini, yang menjadi korban adalah rakyat lagi. Rakyat memang selalu menjadi pelengkap penderita. Hingga kini pun posisi rakyat hanya dijadikan sebagai obyek oleh berbagai pihak yang berkepentingan untuk secara terus-menerus melakukan penindasan. Kisah-kisah di atas yang telah dijelaskan cukuplah menjadi bukti bahwa pendidikan di negeri kita memang benar-benar tidak manusiawi.

\section{Beberapa Kasus Bunuh Diri dan Kekerasan Terhadap Pelajar}

Memang perlu diakui, masa-masa pelajar adalah masa seorang anak sedang berada pada proses peralihan menuju dewasa. Hasrat untuk marah dan memberontak cukup besar. Stres di usia mereka sudah tidak asing lagi, bahkan ada yang sudah menjadi menu sehari-hari. Hanya gara-gara urusan sepele, seorang anak bisa melakukan tindakan yang tidak masuk akal, misal bunuh diri. Pendidikan tidak kenal kaya dan miskin. Setiap orang berhak atas pendidikan. Sekolah sebagai salah satu lembaga pendidikan seharusnya menjadi taman bermain. Di sinilah seharusnya pelajar menemukan jati dirinya, mengenal teman, dan saling curhat. Namun apa yang terjadi di kenyataan sangatlah berbeda. Sekolah semakin menjadi jurang pemisah antara siswa yang kaya dan siswa yang miskin. Siswa kaya berada pada posisi aman, tetapi siswa miskin selalu menjadi korban pendanaan, baik biaya SPP, pembelian buku paket, study tour, dan iuran-iuran lainnya. Semua iuran atas nama pengembangan mutu sekolah dan anak didik.

Di koran harian, kita sering membaca berita kasus bunuh diri pelajar yang sebagian besar masalahnya terkait dengan pendanaan sekolah. Ada yang malu karena nunggak membayar SPP, iuran kelas, pembayaran LKS (Lembar Kerja Siswa), tidak ikut kegiatan wisata, dan lain sebagainya. Kita masih ingat seorang pelajar SMP di Cipunegara, Subang, Jawa Barat, tewas gantung diri karena tidak naik kelas. Remaja bernama Cahyono ini hidup bersama adik dan ayahnya yang bekerja sebagai tukang ojek. Kondisi ekonomi mereka relatif pas-pasan, sehingga ketika menerima rapor dan dinyatakan tidak naik kelas, remaja yang berusia 14 tahun ini mengalami tekanan batin yang sangat berat. Diam-diam, ia memilih jalan pintas bunuh diri. 
Kasus Cahyono pun ditemani oleh kejadian yang menimpa pelajar SMP di Tegal, Jawa Tengah. Hingga kini pelajar tersebut mengalami cacat mental permanen setelah diselamatkan dari usahanya bunuh diri dengan cara menggantung sehingga untuk sesaat otaknya kekurangan pasokan oksigen. Ia tak tahan menanggung malu lantaran tunggakkan SPP yang belum terbayarkan, sementara pihak sekolah terus menagih. Di Cianjur, Jawa Barat, seorang bocah SD bunuh diri setelah diledek teman-temannya karena orangtua tak mampu membiayai acara study tour.

Kasus lain juga terjadi pada hari Jum'at, 17 Juli 2005, di Cikiwul, Bantar Gebang, Kota Bekasi. Warga sekitar dikagetkan dengan peristiwa bunuh diri seorang siswi SMP 10 Bantar Gebang. Vivi Kusrini nekat mengakhiri hidup dengan menggantung diri memakai seikat tali di kamar mandi rumahnya. Menurut penuturan ayahnya, alasan Vivi gantung diri karena malu sering diejek teman sekolahnya sebagai anak tukang bubur. Apalagi menjelang tahun ajaran baru ini Vivi belum punya seragam sekolah (www.liputan6.com, 16/07/ 2005). Kejadian serupa juga menimpa Oman, seorang pelajar kelas enam SD Karang Asih 04, Cikarang, Bekasi, Jum'at (4/6/2004), yang nekat meminum racun tikus karena tidak mempunyai uang untuk membayar biaya ujian akhir nasional (UAN) sebesar seratus ribu rupiah. Kasus Oman ini mengingatkan kembali kasus bunuh diri yang dilakukan Haryanto, murid SD Negeri Sanding IV Garut, pada tahun 2003. Hariyanto juga mencoba bunuh diri karena tidak mampu membayar uang ekstrakurikuler sebesar Rp 2.500 (www.liputan6.com, 05/06/2004).

Mencuatnya kasus-kasus bunuh diri di kalangan pelajar tentu sangat memprihatinkan. Kebanyakan dari mereka berlatarbelakang dari keluarga miskin. Sekolah ternyata telah menjadi '"hantu" bagi pelajar-pelajar miskin. Sekolah begitu menakutkan seperti penjara, disiksa dan diberlakukan tidak manusiawi. Padahal seharusnya di sekolah anak bisa mendapatkan rasa aman dalam artian fisik maupun mental. Belum lagi anak-anak dibebankan kurikulum yang berat dan cara mengajar guru yang menekan atau terkadang merendahkan (Pos Kota Online, 3/07/2007).

Tak hanya kasus bunuh diri saja yang menimpa para pelajar. Kini, kasus pembuhunan terhadap pelajar pun pernah terjadi sebagaimana diberitakan oleh Tempo Interaktif, 08/02/2005. Kita lihat kasus pembunuhan yang terjadi pada Emilia "'Yanti ", Bareto (16 tahun) dan Agusta de Jesus (15 tahun). Kedua pelajar yang berkewarganegaraan Indonesia ini tewas dibunuh oleh sekelompok orang di Dili, Timor Leste akhir Januari 2005. Pembunuhan serupa juga terjadi pada tiga pelajar di Poso, Sulawesi Tengah (www.lantas.metro.polri.go.id, 
30/10/2005) atau di Pasuruan tahun 2007. Masih banyak lagi data-data pembunuhan yang melanda anak-anak pelajar yang tak berdosa.

Kini, pendidikan semakin berani menyingkirkan anak-anak miskin. Kehadiran sekolah-sekolah elite berlabel serba 'plus' dan mengatasnamakan taraf internasional (RSBI, Rintisan Sekolah Berstandar Internasional) ataupun 'IT' alias Islam Termahal telah menjadi sederetan bukti bahwa sekolah benar-benar menyingkirkan anak miskin. Slogan yang sering digembar-gemborkan Eko Prasetyo dalam judul bukunya, Orang Miskin Dilarang Sekolah telah menjadi pil pahit yang harus ditelan oleh sebagian anak negeri ini secara terpaksa. Kemanakah nasib mereka digadaikan?

\section{Sekolah Elite Sebagai Komoditas Bisnis}

Prinsipnya, pendidikan tidak membedakan antara orang kaya dengan orang miskin. Semua orang berhak mendapatkan pendidikan yang sama. Namun di sisi lain, realitas dalam hidup ini selalu diciptakan berpasang-pasang. Ada laki-laki pasti ada perempuan. Ada hitam pasti ada putih. Ada baik pasti ada buruk. Ada kebenaran pasti ada kesalahan. Begitu pula, jika ada si kaya pasti ada si miskin. Keberadaan orang kaya dalam suatu komunitas tertentu dikarenakan sebagian yang lain miskin. Cukup problematis memang.

Landasan filosofis adanya lembaga pendidikan semacam sekolah dan universitas adalah mencerahkan dan menuntun siswa menjadi insan kamil (Mohammad Iqbal, pembaharu asal India). Artinya, para siswa diarahkan menjadi manusia pembelajar yang terus-menerus tidak berhenti mencari kebenaran. Pendidikan pula seharusnya menjadikan warga belajarnya ke arah creator bukan pengekor, mengarahkan untuk menjadi pencipta lapangan pekerjaan bukan budak dan pencari lapangan pekerjaan. Namun kenyataannya, pendidikan selama ini malah lebih menggambarkan sebuah aktivitas besar yang sangat pragmatis dan semata-mata "mengejar target" jangka pendek. Sekolah telah menjadi lahan yang cukup prospektif untuk mengeruk keuntungan sebesar-besarnya. Karena memang setiap makhluk sangat membutuhkan pendidikan. Maka, pendidikan tidak lagi dijadikan sebagai alat perjuangan, tapi tujuan dari perjuangan itu sendiri (Kompas, 31/07/2006: 14). Pertanyaan mendasar adalah, mengapa pendidikan harus hadir di tengah-tengah kehidupan kita? Jawabannya tidak lain adalah untuk mencerdaskan anak bangsa demi kemajuan segala tumpah darah tanah air.

Di kota-kota besar di Indonesia, terutama Jakarta, telah hadir sekolah-sekolah elite dengan nama yang cukup mentereng, gedung yang sangat mewah, pagar yang sangat tinggi, satpam yang begitu gagah, guru yang profesional, serta siswa yang minimal dari kalangan 
menengah ke atas atau kalau tidak berduit. Entah duitnya dari mana, bisa dari ngutang atau malah pinjam dulu dari bank. Cukup ironis. Hal ini tidak lain hanya karena ingin menyekolahkan anaknya di sekolah favorit berkelas nasional atau bahkan internasional. Tentunya kurikulum yang digunakan tidak sembarangan. Ada sekolah yang menggabungkan antara kurikulum Diknas dan Depag. Ada juga yang mengadopsi kurikulum dari luar negeri, misal kurikulum Amerika, Inggris, Jepang, Singapura, Malaysia, atau Australia. Bahkan tak tanggung-tanggung, gurunya pun didatangkan dari luar negeri. Sungguh luar biasa bukan? Tentunya beragam alasan mereka mengapa mengambil kurikulum dari luar. Bagi mereka, kurikulum luar cukup profesional dan berkualitas. Namun memang membutuhkan pendanaan yang cukup tebal.

Karena nilai-nilai elitisme yang ada pada sekolah tersebut, akhirnya berdampak pada biaya mahal yang harus dikeluarkan oleh sekolah untuk menyelenggarakan kurikulum baru, mulai dari menyiapkan kompetensi guru, alat peraga, sarana-prasarana pendidikan, suasana pembelajaran di kelas, perangkat evaluasi dan buku laporan semester (Kompas, 24/04/2006: 14). Bagi sebagian orang tua, biaya mahal asal kualitas si anak terjamin bukanlah masalah. Apalagi jika mereka dari kalangan borjuis. Berpuluh-puluh atau ratusan juta pun siap disumbangkan ke sekolah tersebut asal anaknya benar-benar mendapatkan pendidikan yang bermutu internasional. Sangat luar biasa.

Menjamurnya sekolah-sekolah elite ini berlaku di seluruh jenjang pendidikan, mulai dari TK, SD, SMP, dan SMA. Biasanya, di masing-masing sekolah ada nama sekolahnya. Bagi sekolah Islam, biasanya menamakan sekolahnya dengan nama-nama para sahabat Rasul atau para pemimpin Islam ternama. Entah apa alasan mereka mengambil nama itu. Apakah harapannya sekolah itu bertujuan sesuai dengan nama tokoh yang diambil? Jika memang demikian, alangkah sedihnya, nama para pemimpin Islam yang sangat terhormat tersebut dibajak untuk kemudian dijualbelikan ke khalayak umum. Itulah Islam, sangat seksi untuk diperdagangkan demi kepentingan bisnis.

Selain itu, kita sering menjumpai sekolah-sekolah elite lainnya yang menggunakan label "Islam Terpadu". Islam Terpadu atau Islam Termahal nih? Atau sebenarnya maknanya ya kedua-duanya, kalah mau terpadu ya harus mahal. Nama sekolahnya "Abu Bakar", tapi biayanya “Abu Jahal”. Nama sekolahnya “Abu Dzar Al-Ghifari”, tapi biaya gedungnya amat sangat ngeri. Nama sekolahnya "Umar bin Khotob", tapi SPP-nya besarnya subahanllah top markotob. Nama sekolahnya "Umar bin Abdul Azis", tapi gurunya sadis-sadis. Kini, wilayah agama telah dibawa-bawa untuk mencari uang. 
Perlu diperhatikan pula, kehadiran sekolah elite ada campur tangan dari para pemodal asing atau pengusaha swasta. Dari merekalah terkadang institusi pendidikan elite telah lahir dan menjamur di negeri kita. Jika demikian, maka otonomi lembaga pendidikan semakin terkikis perlahan-lahan. Karena sekolah akhirnya hanya milik beberapa orang saja. Kebijakan tertinggi tetap ada pada pemodal tersebut. Jika hal ini terjadi, sekolah bukan lagi bertujuan edukatif, tetapi sudah menjadi lahan bisnis nan pragmatis.

Pada tingkat perguruan tinggi atau kampus, kita bisa membedakan dengan mudah mana kampus mahal dan mana kampus murah. Begitu juga dengan fakultas atau jurusan, kita juga bisa membedakan mana fakultas yang diisi oleh orang-orang elite dan mana fakultas yang diisi oleh orang-orang menengah ke bawah. Penulis selalu berjumpa dengan temanteman aktivis kampus. Sebagian dari mereka selalu berkeluh kesah tentang fenomena kampus mahal. Tak jarang segelintir dari mereka melakukan aksi sekalipun tak dihiraukan oleh pimpinan kampus.

Ada seorang mahasiswa di Jogja yang bercerita kalau dirinya lulus seleksi masuk di kampus UI Jakarta untuk salah satu jurusan sosial. Namun, dirinya tak jadi mengambil kuliah di UI lantaran mendapatkan surat yang salah satu isi suratnya mengatakan, bahwa SPP per semester di atas 20 juta rupiah. Gimana tuh? Selain itu, fakultas-fakultas semisal kedokteran, farmasi, kesehatan, dan yang sejenisnya selalu diidentikkan dengan fakultas elite. Fakultasfakultas ini seolah hanya diisi oleh orang-orang yang berduit. Untuk uang masuknya saja sudah puluhan bahkan ratusan juta. Sedangkan fakultas sosial, budaya, dan filsafat pasti diisi oleh orang-orang menengah ke bawah. Pada akhirnya, institusi pendidikan kita hanya melahirkan dikotomi sosial yang dilematis.

Tak berhenti di situ saja, sejak beberapa tahun yang lalu telah menjamur perguruan tinggi swasta yang bertujuan mencetak calon sarjana siap kerja. Program yang mereka jual pun tak jauh-jauh dari bisnis, ekonomi, interpreneur, dan informatika. Intinya, mereka menjual program-program yang sesuai dengan selera pasar. Para calon mahasiswa pun diiming-imingi, bahwa setelah lulus dari kampus tersebut pasti mendapatkan pekerjaan atau pasti diterima di perusahaan bergengsi internasional. jika kampus mereka tak laris di pasaran, akan tutup begitu saja. Kemudian mendirikan kampus baru lagi sesuai dengan minat pasar. Jika pendidikan kita demikian, tak lain kita hanya didik menjadi budak ilmu pengetahuan. Kita dicetak hanya menjadi pemburu lapangan pekerjaan bukan pencipta lahan baru.

Di awal saat kita mendaftarkan diri di jurusan mana yang kita pilih, kita pasti masih ingat dengan sejumlah pertanyaan, seperti: Kalau kamu ambil jurusan ini mau jadi apa? Kalau kamu sudah lulus nanti mau kerja dimana? Serta sederet pertanyaan lain yang 
terkadang mengganggu pikiran kita. Pertanyaan-pertanyaan semacam itu bisa muncul dari keluarga, teman, atau orang lain. Pada akhirnya, kita terbelenggu oleh cercaan-cercaan tersebut sehingga seolah-olah membayang aktivitas keseharian kita bahkan bisa terbawa mimpi. Kita menjadi takut kalau mengambil jurusan filsafat, tidak akan perusahaan yang membutuhkan filosof. Mana ada iklan koran yang berbunyi: "Dibutuhkan seorang filsuf sekarang juga dengan kriteria sebagai berikut, dst..." atau "Dibutuhkan politisi cerdas untuk menjadi ketua partai politik". Jika ada, mungkin hanya koran milik orang gila saja. Hampir semua iklan selalu berbunyi: Dibutuhkan karyawan untuk posisi sales executive, staf administrasi, accounting, public relation, satpam, atau area general manager. Semua posisi seolah memberikan harapan.

Inilah potret pendidikan kita. Pendidikan yang tak lagi memberikan rasionalitas dan keberpihakan pada sis-sisi kemanusian kita. Pendidikan tak lagi mengajarkan mana yang benar dan mana yang salah. Pendidikan tak lagi memberikan kebebasan untuk hidup layak. Pendidikan telah menjadi lahan bisnis bagi segelintir pemilik modal. Karena itu, jika menginginkan sekolah yang berkualitas tinggi dengan segala fasilitas yang mewah, haruslah dibayar dengan harga yang tinggi pula. Sungguh menyedihkan!

\section{Pola Hubungan Guru, Sis wa, dan OSIS}

Selain membahas persoalan di atas, kita perlu juga membahas apa yang terjadi di dalam sekolah itu sendiri, terutama yang terkait dengan pola komunikasi antar warga sekolah. Kita tentu masih ingat dengan pepatah lama, "Guru itu digugu lan ditiru". Hampir semua orang sepakat dengan kalimat panutan tersebut. Tapi bagimana dengan kenyatannya, apakah guru benar-benar diharapkan sesuai dengan keinginan para siswa? Bagaiamana hubungan selama ini yang terjadi antara guru, siswa, dan pengurus Organisasi Siswa Intra Sekolah (OSIS)? Yuk, kita simak selanjutnya.

Guru merupakan sosok yang memikul tugas cukup berat. Dari sekadar mengajar di kelas, membimbing dan mengarahkan secara personal, serta memahami perkembangan anak selama ia menjadi siswa di mana guru tersebut berada. Belum lagi pekerjaan administrasi kantor yang harus segera diselesaikan. Karena tugas inilah, guru sering mendapatkan penghargaan sebagai pahlawan tanpa tanda jasa. Artinya, kesejahteraan yang diterima oleh guru tidak sebanding dengan kerjanya yang cukup berat dan melelahkan. Karena alasan ini pula kita harus hormat dan patuh terhadap guru. Guru dituntut harus mampu menjadi teladan bagi seluruh siswanya, mampu mengarahkan mereka akan kebenaran, serta mampu membuat para siswa sadar untuk membela korban penindasan dan melawan para penindas. Sekolah 
adalah ruang untuk mendapatkan itu semua dan guru merupakan partner yang dianggap mampu untuk menyelesaikan itu.

Siswa adalah peserta belajar sekaligus menjadi guru pada waktu yang bersamaan. Siswa adalah subyek pembelajar, bukan obyek pembelajaran. Karena subyek pembelajar, maka siswa sesekali harus mampu tampil di depan untuk mengutarakan pengalamanpengalaman yang pernah dia dapatkan dalam kehidupan ini. Guru hanya memberikan ruang bagi siswa untuk berekspresi. Siswa bisa diibaratkan seperti gelas kosong yang harus diisi oleh sesuatu yang bermanfaat. Di sinilah tugas guru untuk mengisi gelas kosong itu dengan ilmu pengetahuan yang bermanfaat. Karena itu, guru harus mampu menjadi seorang motivator, inspirator, dan pembangikit semangat para siswa, jangan malah membuat mental siswa menjadi kerdil dan nggak Pe-De untuk tampil di depan.

Untuk mencari sosok yang mampu menjadi motivator, inspirator, dan pembangkit semangat bukanlah pekerjaan yang mudah. Ini sangat sulit sekali dan mungkin hanya satu banding seribu. Mengapa penulis mengatakan demikian? Karena masih banyak guru yang beralasan bahwa dirinya menjadi guru hanya cukup datang ke kelas, mengajar, dan menerangkan pelajaran yang menjadi tugasnya. Jika ada PR maka para siswa diminta untuk mengerjakannya, dan pulang ke rumah. Cukup itu saja! Setelah semua tugas administrasi dikerjakan, maka mereka harus menerima gaji. Kalau demikian caranya, semua orang pun bisa menjadi guru. Ternyata jadi guru itu simpel, datang, duduk, menerangkan, memberi tugas, dan pulang. Kalau begini caranya, memang tidak sepatutnya lagi kalau guru mendapatkan penghargaan sebagai pahlawan tanpa tanda jasa, tetapi mendapatkan penghargaan pahlawan yang sangat membutuhkan jasa (baca: gaji).

Selain itu pula, hubungan yang terjadi antara guru dan siswa masih seperti majikan dengan budak. Guru berada di atas, siswa hampir selalu berada di bawah. Guru mengajar, siswa belajar. Guru tahu segalanya, siswa tidah tahu apa-apa. Guru berpikir, siswa dipikirkan. Guru bicara, siswa mendengarkan. Guru mengatur, siswa menuruti. Guru bertindak, siswa mengikuti bagaimana cara bertindak sesuai dengan tindakan gurunya. Guru memilih topik yang akan diajarkan, siswa tinggal menerima materi yang diajarkan oleh guru. Guru adalah subyek, siswa hanya obyek dari sistem pembelajaran yang berjalan. Jika demikian yang terjadi, maka tak lain sekolah hanyalah sebuah institusi yang akan menghasilkan robot-robot ilmu pengetahuan. Siswa tidak lain hanya sekedar foto copi dari gurunya. Iya kalau foto copiannya bagus, kalau jelek dan tidak berkualitas bagaimana? Bisa gawat kan. Meminjam istilah Nagabonar, "Apa kata dunia jika pelajar hanya foto copi guru?" 
Inilah yang dikatakan oleh Paulo Freire (pemikir asal Brazil) sebagai pendidikan gaya bank yang harus segera dimusnahkan dari dunia pendidikan kita. Kita tentu masih ingat dengan tujuan pendidikan itu sendiri, yakni membantu manusia menemukan hakekat kemanusiaannya. Artinya, pendidikan harus mampu mewujudkan manusia seutuhnya. Pendidikan berfungsi melakukan proses penyadaran terhadap manusia untuk mampu mengenal dan memahami relitas kehidupan yang ada di sekelilingnya. Dengan adanya pendidikan, diharapkan manusia mampu menyadari potensi yang ia miliki sebagai makhluk yang berpikir. Potensi yang dimaksud adalah potensi ruhaniyah (spiritual), nafsiyah (jiwa), aqliyah (pikiran), dan jasmaniyah (tubuh). Dengan melakukan proses berpikir, manusia akan menemukan eksistensi kehadirannya sebagai makhluk yang telah diberi akal oleh Tuhan Yang Maha Esa. Di sinilah akhirnya pendidikan bertujuan melakukan proses "humanisasi" (memanusiakan manusia) yang berujung pada proses pembebasan (Al-Hamdi, 2006: 73-74). Namun itu semua tidak kita dapatkan di sekolah, karena sekolah telah berubah menjadi "penjara suci". Sungguh amat menyedihkan.

Selain itu, kita akan melihat pola hubungan yang terjadi antara pengurus sekolah dengan pihak sekolah. Seperti yang terjadi antara guru dan siswa, maka pola hubungan antara pihak sekolah dengan pengurus sekolah seperti layaknya sang raja dengan bawahan. Raja tinggal memberikan perintah apa yang dia inginkan dan bawahan tinggal melaksanakan apa yang diperintahkan oleh sang raja. Tentu tidak ada komunikasi antara kedua belah pihak, apalagi terjadi semacam dialog partisipatoris. Ini mustahil. Karena itu, keberadaan OSIS, tak lain hanya sekadar pelengkap pelaksana dari keputusan-keputusan sekolah. Tidak ada ruang bagi pengurus sekolah untuk memberikan masukan atau kritikan atas kebijakan-kebijakan yang telah ditetapkan oleh pihak sekolah.

Jika demikian, kembali lagi pada pertanyaan, di manakah fungsi sekolah sebagai lembaga yang memanusiakan manusia? Membawa para siswa dari kegelapan menuju pencerdasan? Kiranya pola hubungan yang terjadi antara guru, siswa, dan pengurus sekolah harus dibuat dengan sedemikian dialogis, agar tujuan dari sekolah sebagai institusi pendidikan dapat berjalan sebagaimana mestinya. Bagaimana menurutmu, wahai pelajar?

\section{Kritik Atas Ekstrakurikuler Sekolah}

Selain mendapatkan pelajaran resmi dari pagi hingga siang hari, para siswa juga mendapatkan materi tambahan atau lebih enak didengar dengan ekstrakulikuler pada sore hari. Ektranya pun bermacam-macam. Ada jurnalistik, Kelompok Ilmiah Remaja (KIR), teater, olahraga (sepak bola, bulu tangkis, tenis meja, voli, dll), pramuka/Hizbul Wathan, 
tonti, seni bela diri, qiroah, kaligrafi, dan lain sebagainya. Masing-masing sekolah tentu memiliki kebijakan sendiri-sendiri terhadap ekstra apa saja yang diperuntukkan bagi para siswanya. Ketika awal menjadi siswa baru atau setiap awal ajaran tahun baru, para siswa tentu sudah harus menentukan mana pilihan ektra yang menarik bagi dia. Di sebagian sekolah biasanya pihak guru memberikan lembar bagi para siswa untuk menentukan satu atau dua pilihan ektrakulikuler yang harus dimiliki masing-masing siswa.

Tujuan diadakannya kegiatan ektrakulikuler sebagai penyeimbang kegiatan-kegiatan sekolah. Ketika pada pelajaran pagi hari mereka sangat penat, maka dengan adanya kegiatan ekstra ini meraka dapat lega dan santai dengan suasana yang lebih enjoy. Mereka dapat bertemu dengan teman baru antarkelas atau dengan kakak dan adik kelas. Pengalaman baru tentunya akan mereka dapatkan dari kegiatan eksta ini. Selain itu juga, dengan adanya kegiatan ekstra ini potensi dan bakat terpendam para siswa bisa muncul ke permukaan. Harapannya, ketika ada kompetisi baik tingkat kabupaten, provinsi, maupun nasional, para siswa bisa saling adu ketangkasan dan membawa nama harum sekolah dan dirinya sendiri. Di sisi lain, dia akan mendapatkan beasiswa dari pihak sponsor acara.

Namun, itu semua belum bisa terlaksana dengan sedemikian rapi. Masih saja ada kekurangan di sana-sini. Kegiatan ekstra belum mampu berjalan dengan maksimal. Kita masih sering menjumpai bahwa kegiatan KIR hanya milik siswa-siswi yang pintar dan cerdas. Yang bohoh tidak pantas berada di komunitas ini. Apalagi kegiatannya sangat melelahkan. Hal ini menyebabkan hanya beberapa siswa saja yang ikut KIR. Mungkin tak lebih dari 20 orang. Itu pun kalau aktif semua. Belum lagi kalau guru ekstranya sering tidak datang. Padahal seharusnya KIR bisa mejadi familiar juga di telinga semua siswa. Tidak mendiskreditkan siswa yang pintar dengan siswa yang di bawah rata-rata.

Kegiatan jurnalistik mungkin cukup diminati oleh sebagian siswa. Dengan kegiatan reportase, menulis cepen, mencari berita, menulis pusi, membuat mading (majalah dinding), dan jenis kegiatan lainnya, para siswa bisa asyik dalam mengerjakannya. Di kegiatan inilah, para siswa dituntut untuk profesional dalam menyajikan sebuah media sekolah. Tapi terkadang sekolah tidak terlalu ikhlas sepenuhnya dalam membimbing siswa. Sebagai contoh, dipersulitnya izin wawancara saat jam pelajaran atau kalau tidak malah tidak diizinkan sama sekali. Padahal si anak tersebut harus wawancara dengan tokoh pada jam 10 pagi dan tokoh itu hanya bisa pada jam itu. Terkadang pun persoalan pendaanaan untuk penerbitan selalu ditunda-tunda dengan berbagai macam alasannya.

Dalam pramuka atau tonti, siswa diajarkan untuk disiplin terutama dalam barisberbaris. Dengan komando satu orang, para siswa dididik bak militer. Mereka dilatih agar 
menjadi siswa pemberani alias tidak cengeng. Jika ada yang salah dihukum push up atau scot jump. Itu semua bagus dan memang diperlukan. Tapi akhirnya kita hanya mendidik para siswa menjadi robot yang harus mengikuti satu komando. Kegiatan ini sama saja mengekang kreativitas siswa di sekolah. Kalau kita pikir-pikir, apa manfaatnya perintah balik kanan, hadap kanan, hadap kiri, dan seterusnya. Paling-paling ya cuma capek saja. Karena itu, kita perlu ingat kembali keberadaan kegiatan ekstra di sekolah. Apakah kegiatannya memang benar-benar sesuai dengan tujuan pendidikan itu sendiri, memanusiakan manusia dan tidak sekedar transfer of knowledge, atau hanya sekedar menggugurkan kewajiban tahunan tanpa ada tujuan yang jelas. Ini sangat menyedihkan sekali. Para siswa juga harus bersikap berani dan kritis terhadap gejala-gejala semacam ini yang muncul di sekolah kalian. Karena kalianlah sekolah bisa menjadi baik atau buruk.

Kegiatan ekstra yan perlu mendapatkan perhatian juga adalah adanya milad atau ulang tahun sekolah. Kegiatan ini selalu diadakan tiap tahun. Memang tidak semua sekolah mengadakannya, tetapi hanya sekolah-sekolah elit yang berlimpah uang tentunya. Prinsipnya bagus ketika acara-acara semacam ini diadakan rutin tahunan. Dengan adanya ulang tahuan sekolah, kita bisa berpikir bagaimana kemajuan sekolah di masa yang akan datang. Tapi, perlu diingat juga, bahwa jangan sampai kegiatan ini malah menguras banyak dana. Dana yang seharusnya bisa dimanfaatkan untuk menunjang fasilitas sekolah, tetapi telah habis dengan sia-sia hanya untuk acara ulang tahun yang remeh-temeh. Apalagi kalau acara semacam ini hanya dijadikan ajang hura-hura, pentas seni, tanpa ada refleksi untuk kemajuan sekolah tersebut.

Kiranya sekolah harus kembali merefleksikan diri terhadap kegiatan-kegiatan ekstra yang selama ini telah dilakukan. Pada prinsipnya kegiatan ekstra cukup bagus untuk menunjang kreativitas para siswa. Tapi di sisi lain, harus dipertimbangkan pula aspek manfaat dan keuntungannya, terutama untuk perkembangan dan kualitas dari sekolah tersebut.

\section{Kesimpulan}

Di sinilah pada akhirnya sekolah telah menjadi penjara baru bagi warga belajarnya. Orang menjadi takut untuk datang ke sekolah. Banyak monster yang siap menyiksa para warga belajarnya dengan setumpuk tugas, wajah seram para guru, dan rumitnya mata pelajaran karena ketidakpintaran cara guru menyampaikan materi. Para guru pun mempunyai alasan yang pamungkas: Ini semua demi mengejar target kurikulum. Jika demikian yang terjadi, apa kita hanya diam saja? Apakah rela sekolah beralih fungsi menjadi penjara model 
baru? Apa kita tidak malu ketika para siswa mengatakan, bahwa hanya ada tiga hal yang paling disukai di sekolah: saat jam kosong, saat istirahat, dan saat-saat menjelang pulang sekolah? Dan setelah lulus mengikuti UN, mereka benar-benar seperti keluar dari penjara. Dengan penuh kegembiraan yang memuncak, kebebasan itu mereka rayakan dengan mencoret-coret seragam, konvoi di jalan raya beramai-ramai, hingga berteriak sekencangkencangnya pada dunia: Kami Bebas, Kami Bebas, Kami Bebas Dari Penjara Sekolah!

Marilah kita bersama-sama (baik para pembuat kebijakan, pelaksana kebijakan, dan raja-raja kecil di tingkat sekolah) membuat terobosan yang cerdas agar Indonesia dapat melahirkan manusia-manusia kreatif, calon pemimpin-pemimpin yang tidak hanya mampu menggebrak meja parlemen, tidak sekadar pemimpin yang berani omong kosong dan menjual suara rakyat, tetapi menciptakan pemimpin yang dapat mengguncang peradaban dunia melalui dunia pendidikan. Selamat belajar, para penuntut ilmu!

\section{Referensi}

Al-Hamdi, Ridho. Melawan Arus: Catatan Harian Seorang Aktivis. Yogyakarta, Resist Book: 2006

Asyarie, Musa. Filsafat Islam, Sunnah Nabi dalam Berpikir. Yogyakarta: LESFI, 2002

Hardiman, Francisco Budi. Kritik Ideologi, Pertauatan Pengetahuan dan Kepentingan. Yogyakarta: Kanisius, 1993

Harrison, Lisa. Metodologi Penelitian Politik. Kencana Predana. Jakarta: Media Group, 2007

Isma'il, Fuad Farid dan Abdul Hamid Mutawalli. Cepat Mengusai Ilmu Filsafat. Yogyakarta: Ircisod, 2003

Koran Jawa Pos, 20 Desember 2007

Koran Kompas, 9 Februari 2006.

Koran Kompas 24 April 2006

Koran Kompas, 31 Juli 2006

Koran Kompas , 24 Maret 2007

Koran Kompas, 19 Desember 2007

Kuntowijoyo. Muslim Tanpa Masjid. Bandung: Mizan, 2001

Majalah Kuntum, Edisi 257/Mei 2006

Majalah Gerbang, Edisi 5 Th. III November 2003

Majalah Basis, No. 05-06, Tahun ke-53, Mei-Juni 2004

Malay, Ekky. Ali Syariati, Filosof Etika dan Arsitek Iran Modern. Jakarta: Teraju, 2004 
Marsh, David dan Gerry Stoker. Theory and Methods in Politial Science. Hampshire: Palgrave Macmilla, 2002

Moleong, Lexy J. Metodologi Penelitian Kualitatif. Bandung: PT Remaja Rosdakarya, 2004 Pos Kota Online, 3 Juli 2007

Sarantakos, Sotirios. Social Research. Melbourne: Macmillan Education Australia PTY LTD, 1993

www.lantas.metro.polri.go.id, 30 Oktober 2005

www.liputan6.com, 5 Juni 2004

www.liputan6.com, 16 Juli 2005

www.tempointeraktif.com, 08 Februari 2005 